\title{
FACTORS OF HUMAN CAPITAL MODERNIZATION IN THE CONTEXT OF INSTITUTIONALIZATION OF INFORMATION ECONOMY
}

\author{
Maryna Radieva and Viktoriia Kolomiiets
}

\begin{abstract}
The constant institutional transformations of society make it necessary to study their influence on the development of human capital and the dependence of the development of human capital on the conditions of institutionalization of the information economy. The aim of this scientific work: to identify the existence of a dependence of the development of human capital on the institutionalization of society in the information economy, to build correlationregression models of the dependence of the development of human capital on the level of development of the country's institutional system in the information economy. The study has proved the hypothesis that there is a relationship between the human capital index and the development of the country's institutional system. The selection of indicators describing the dependence of the development of human capital on the development of the country's institutional system in the information economy, which included political, legal, economic, social, institutional, using an expert analysis method, is carried out. For a multifactorial phenomenon, as the dependence of the development of human capital on the level of development of the country's institutional system in the information economy, the methods of multiple correlation and regression analysis are used. The study was conducted for 157 countries of the world for which the World Bank determined the country's human capital index in 2018. As a result, correlation equations are constructed that give the dependence of the development of human capital on the level of development of the country's institutional system in the information economy. They should determine the feasibility of material costs for the development of a separate factor of the influence of the institutional system for the development of human capital. The constructed models have shown that the greatest correlation between the human capital index and the selected indicators of the country's institutional system development exists: for countries with a high human capital index and high gross national income per capita - government labor costs, tax burden; for countries with an average human capital index and with an average gross national income per capita, to which Ukraine belongs, - freedom of the labor market, protection of property rights; for countries with a low human capital index and low gross national income per capita effectiveness of the judicial system, government decency. The study of the dependence of the development of human capital on the development of the institutional system will interest not only the scientific layers of countries, but also state and government institutions.
\end{abstract}

Keywords: human capital, human capital index, institutionalization, institutional system, information economy

JEL Classification: E02, E14, E24 


\section{Authors:}

\section{Maryna Radieva}

Melitopol Institute of Public And Municipal Administration of the Classic Private University, 8/2, Kakhovske shose, Zaporizka Region, Melitopol, Ukraine, 72311

E-mail:ra_va@ukr.net

https://orcid.org/0000-0003-2288-3388

\section{Viktoriia Kolomiiets}

Melitopol Institute of Public And Municipal Administration of the Classic Private University, 8/2, Kakhovske shose, Zaporizka Region, Melitopol, Ukraine, 72311

E-mail:vik2005vik@meta.ua

https://orcid.org/0000-0003-3427-8986

Citation: Radieva, M., \& Kolomiiets, V. (2019). Factors of human capital modernization in the context of institutionalization of information economy. Virtual Economics, 2(4), 26-45. https://doi.org/10.34021/ve.2019.02.04(2)

Received: July 19, 2019. Revised: August 3, 2019. Accepted: August 23, 2019.

(C) Author(s) 2019. Licensed under the Creative Commons License - Attribution 4.0 International (CC BY 4.0)

\section{Introduction}

The information economy is based on human capital. It is from the creativity and creative achievements of a person that the development of the latest technologies, technological and social progress of society depends. It should also be noted that all the achievements of mankind are aimed at satisfying the diverse needs of man as a single object and human capital. Thus, human capital in the information economy acts as a consumer of goods and as a resource, without which it is impossible to imagine the development of society.

The institutionalization of the country's environment, as a process of determining and fixing norms, contributes to the development of human capital, helps individuals to feel comfortable in an institutional society, and allows the country to function exclusively in accordance with constitutional norms and rules. But in the context of the dynamic development of the information economy, the influence of the institutional environment on a person, its wellbeing, and the development of human capital are not considered enough. It is necessary to study the feasibility and significance of the influence of the institutional environment on the development of human capital.

The aim of this scientific work: to identify the existence of a dependence of the development of human capital on the institutionalization of society in the information economy, to build correlation-regression models of the dependence of the development of human capital on the level of development of the country's institutional system in the information economy. 
The development of these correlation-regression models will make it possible to calculate the economic feasibility of material investments in the development of individual components of the institutional system for the development of the country's human capital.

\section{Literature review}

In the hierarchy of research, human capital is at the top of the information economy. Significant results in the study of various aspects of human capital achieved by scientists $\mathrm{G}$. Becker, N. Bhutoria, B. Weisberg, L. Gratton, J. Mincer, L. Turou, T. Schulz.

Human capital is defined as a key result of the development of human resources (Ali et al., 2018; Bryukhovetska \& Chornaya, 2015; Kolomiiets \& Golovkova, 2017; Dalevska et al., 2019; Mahmood \& Alkahtani, 2018; Siddiqui \& Rehman, 2016; Liashenko, 2016; Flamholtz et al., 2002). A number of scientists are inclined towards the need for investments in the development of human resources in order to develop and maintain them in the future and preserve them in the present (Bryukhovetska \& Chornaya, 2015; Kolomiiets \& Golovkova, 2017; Kwilinski et al., 2019; Pajak et al., 2016; Liashenko \& Pidorycheva, 2019; Radieva, 2018). At the same time, it is recognized that human capital stimulates and ensures the formation of the economic viability of a person, enterprise, and state (Liashenko, 2017; Radieva, 2018).

The conceptual definition of human capital is the subject of research by G. Becker (1964). He aligned theoretical studies with practical results that established a positive correlation between the incomes of individuals and their level of education, employment, and duration of study (Becker, 1964).

Many researchers have studied the question of what factors and factors affect human capital. The search for a connection between human capital and the country's economic growth was carried out by M. Ali, A. Egbetokun et M. Memon (2018). They emphasize that the main factors influencing human capital are economic and institutional indicators and draw conclusions from empirical studies (Ali et al., 2018). The theoretical formulations of the relationship between human capital and a country's growth consistently suggest that the knowledge embodied in a person is important for innovation, productivity and dynamic growth (Ali et al., 2018).

N. Mahmood et N. Alkahtani (2018), based on data for the period 1970-2017, and also by applying a regression model with a distributed lag, investigate the impact of human resources and the development of the financial market on the country's economic growth. The results of the study show that the interaction of human capital and human resources, as well as capital and the financial market, has a positive effect on economic growth (Mahmood \& Alkahtani, 2018).

Studies of A. Siddiqui et A. Rehman (2016) are devoted to regional features of the development of human capital. They study what factors ensure the different development of human capital and emphasize the importance of spending on education and maintaining the health of human capital. The importance of human capital for regional development, its impact 
on economic development is noted not only for individual countries, but also for entire regions and locations (Lyashenko, 2017).

V. Lyashenko et I. Pidorycheva (2019) note that the main source of economic growth and industrial development for developing countries is their absorption capacity or ability to use world knowledge and technology. The main ones are foreign direct investment, trade, research and development, codified knowledge flows and human capital.

A review of literary sources shows that scientific studies of the dependence of the development of human capital in the information economy are focused on the manifestation of the influence of exclusively economic factors or the correlation between the growth of human capital and economic growth of the country. The influence of the institutional system on human capital remains without the attention of scientists. Meanwhile, in the conditions of informatization of society, it is institutionalization that can give a general synergistic effect in politics, economics, and the social sphere and lead to the rapid development of human capital.

Institutional theory is based in the works of T. Veblen, developed by J. Commons, W. Mitchell, J. Gelbraith. The founders of the modern theory of institutionalism consider R. Coase, D. North. Institutionalization of a country is an ongoing process. Intensive institutional transformations that determine the development of countries with economies in transition guide the vector of change in all areas. At the same time, human capital is limited in its actions by the institutional structure of society (Radieva, 2018). Institutional changes lead to the emergence of new and the withering away of old rules of behavior and appropriate mechanisms to ensure their transformation (Tkach et al., 2018). There are also changes in the structure and nature of economic relations within the framework of the existing rules for their participants. Such an approach to the determination of institutional changes takes into account that the current rules mean not only the emergence of new attitudes, but also new mechanisms that ensure their compliance with entities (Tkach et al., 2018).

Along with the positive effects of institutionalization, other consequences are noted. Among the many negative factors, the main ones are the weakness of the government, political instability, the judicial system, the right to apply contract rights and the low level of development of the institution of property rights, which in general can indicate an institutional crisis in the country (Shashyna, 2018).

The influence of the institutional environment is manifested as formed under the influence of a certain institutional system of human capital and its actual ability to produce the gross product and use it effectively (or inefficiently) to manage human capital.

The constant institutional transformations of society make it necessary to study their influence on the development of human capital and the dependence of the development of human capital on institutionalization, especially in the context of the information economy. 


\section{Methods}

The methodological basis of the study is the fundamental principles of economic theory, the development of information economy, institutional theory, presented in classical and modern scientific works of scientists on human capital and human resource management, economic development, institutionalists.

To achieve this goal and solve certain problems, let's use a set of scientific methods that ensure the conceptual integrity of the study, in particular: structural-logical analysis and generalization - for the logical structural construction of the work; economic-statistical and comparative analysis - for identification of the dynamics, level of development of human capital, establishing the dependence of the development of human capital and the institutional system of the country; grouping and systematization - for ranking countries according to the GNI level, identifying factors of influence on human capital, statistical and mathematical methods (multivariate correlation and regression analysis) - for building economic and mathematical models of the dependence of the human capital index on the level of institutional development of the country.

Measuring the dependence of the development of human capital on the institutionalization of society in the context of the information economy is quite difficult. Practical measurements at the individual, collective, regional, national levels require the construction of a number of indicators. It is even more difficult to develop a methodology for measuring the dependence of human capital on the level of institutional development of a country. Separate methods require comparing studies between people, organizations, and states.

\section{Results and Discussion}

The information economy has contributed to a shift in emphasis closer to the consumer market, where consumer awareness and demand have increased. This has led to a shorter life cycle of products and services, making innovation and differentiation of products and technologies critical to competitiveness. Existing indicators and tools have lost the ability to provide a comprehensive and sufficient picture of the country's effectiveness and status. There were no specific values, quantitative and qualitative descriptions (which existed, for example, for equipment, stocks) of human capital of the country's economy. The measurement of the dependence of the development of human capital on various factors has become a problem when trying to find an acceptable form and criteria for determination.

In general, various dimensions of human capital are the process of identifying, defining, measuring, and sharing information on the importance of human capital for decision making (Roslender, 2009).

When determining the dependence of the development of human capital on various factors, it should be borne in mind that human capital, in appearance, is invisible and closely related to 
the place, time and purpose, as well as the degree of protection of intellectual property, own developments (patents, licenses, know-how), legal documents on them.

Theoretical studies provided the basis for determining indicators describing the influence of factors on the development of human capital, and their grouping is shown in Table 1.

Table 1. Indicators of factors of influence on the development of human capital of the national economy by groups

\begin{tabular}{|c|c|c|c|}
\hline Groups & & Indicators of factors & \\
\hline \multirow{2}{*}{$\begin{array}{l}\text { Political and legal } \\
\text { factors }\end{array}$} & Regulatory policy & Corruption level & Bureaucracy level \\
\hline & Trade and economic policy & $\begin{array}{c}\text { Law enforcement } \\
\text { effectiveness }\end{array}$ & $\begin{array}{c}\text { Level of compliance } \\
\text { with laws }\end{array}$ \\
\hline \multirow[b]{2}{*}{ Economic factors } & GNI per capita & Investment rate & Minimum wage \\
\hline & Consumer price level & Unemployment rate & $\begin{array}{l}\text { Labor migration } \\
\text { rate }\end{array}$ \\
\hline \multirow[b]{2}{*}{ Social factors } & Birth rate & Mortality rate & Healthcare costs \\
\hline & Culture expenses & $\begin{array}{l}\text { Environmental performance } \\
\text { index }\end{array}$ & $\begin{array}{c}\text { Pension } \\
\text { replacement rate }\end{array}$ \\
\hline \multirow{2}{*}{$\begin{array}{l}\text { Organizational and } \\
\text { administrative and } \\
\text { information and } \\
\text { communication factors }\end{array}$} & $\begin{array}{c}\text { Country competitiveness } \\
\text { index }\end{array}$ & Employee competitiveness & $\begin{array}{c}\text { Access to the } \\
\text { Internet }\end{array}$ \\
\hline & Computer software & $\begin{array}{c}\text { Access to communication } \\
\text { systems }\end{array}$ & $\begin{array}{c}\text { Provision of } \\
\text { communication } \\
\text { systems }\end{array}$ \\
\hline \multirow{2}{*}{$\begin{array}{l}\text { Scientific and } \\
\text { technological factors }\end{array}$} & Number of new technologies & Innovation costs & Science expenses \\
\hline & Research costs & Energy saving costs & $\begin{array}{c}\text { Intellectual property } \\
\text { protection }\end{array}$ \\
\hline \multirow{4}{*}{ Institutional factors } & Business freedom & Labor market freedom & Monetary freedom \\
\hline & Freedom of trade & Freedom of investment & Financial freedom \\
\hline & Fiscal health & Government spending & Tax burden \\
\hline & Government decency & Judiciary effectiveness & $\begin{array}{c}\text { Protection of } \\
\text { property rights }\end{array}$ \\
\hline
\end{tabular}

Source: own research.

The group of political and legal indicators includes: regulatory policy, corruption level, bureaucracy level, trade and economic policy. The group of economic indicators includes unemployment, investment, minimum wage, consumer price level. The group of social indicators includes the birth rate, mortality rate, health care costs, cultural expenses, environmental performance index, pension replacement rate, labor migration rate, gender equality.

An acceptable measurement of human capital can be based on an equation where the cost of an employee's labor, wages, and other benefits will be proportional to economic benefits, such 
as turnover or gross profit. But this approach does not take into account the opportunities created by human capital for developing a business or measuring the benefits of developing practices and processes. A common problem is to measure the value of hidden values: how much hidden factors of creating the value of human capital, such as rare skills, unique knowledge, skills, social skills, implicit knowledge, could be better used for the development of the country if they are recognized and discovered.

The study hypothesizes that there is a relationship between the human capital index and the development of the country's institutional system.

The selection of indicators describing the dependence of the development of human capital on the development of the institutional system of the country, which includes political, legal, economic, social, institutional, using an expert method of analysis, is carried out.

When calculating the reliability of these indicators, the Cronbach's alpha coefficient value of 0.78 is obtained, which confirms the consistency of the characteristics within the group and the possibility of combining them into a single group. The relationship between the indicators shows that the variance between them is at an acceptable level in the range of 0.25-0.55.

The Cronbach's alpha coefficient shows the internal consistency of characteristics describing a single object, but is not an indicator of the homogeneity of an object. The coefficient is often used in expert assessments when building tests and to test their reliability.

The standardized Cronbach's alpha coefficient is calculated by the formula:

$$
a_{s t}=N \times \hat{r}
$$

where $N$ - the number of investigated components;

$\hat{r}$ - the average correlation coefficient between the components.

Cronbach's alpha can take the values: $>0.5$ - low consistency, $>0.6-$ doubtful consistency, $>$ 0.7 - sufficient consistency, $>0.8$ - good consistency, $>0.9$-very good consistency.

For multifactorial models or phenomena, which is the dependence of the development of human capital on the level of development of the country's institutional system in the context of the information economy, it is advisable to use methods of multiple correlation and regression analysis, which allow to study and quantify the internal and external investigative relationships between the factors forming the model and establish patterns functioning and development trends of the investigated effective trait. In a real economy, probabilities (stochastic) relationships between effective indicators and factors. The main task of the correlation and regression analysis methods is to analyze statistical data to identify the mathematical relationship between the studied features and to establish, using correlation 
coefficients, a comparative estimate of the density of the relationship, which has a specific numerical expression.

The following indicators are taken as evidence to identify the dependence of human capital development on a country's institutionalization in the information economy: human capital indices of 157 countries (The Human, 2018), which are combined into 3 groups according to the level of GNI per capita; indicators of the development of the country's institutional system are also combined into 3 groups according to the level of GNI per capita (Index, 2018). The basis for calculating the indicators of the development of the country's institutional system is the components of economic freedom (Index, 2018). The study was conducted for 157 countries of the world for which the World Bank determined the country's human capital index in 2018 (Index, 2018). The resulting correlation equations should determine the feasibility of material costs for the development of a separate component of the institutional system for the development of human capital. The study of the dependence of the development of human capital on the development of the institutional system will interest not only the scientific layers of countries, but also state and government institutions. The countries were also ranked by gross national income per capita, which is shown in Table 2 (Jahan et al., 2018).

Table 2a. Ranking countries by GNI per capita (part 1)

\begin{tabular}{cccc}
\hline & \multicolumn{3}{c}{ Countries } \\
\hline \multirow{2}{*}{$\begin{array}{c}\text { low GNI per capita (less } \\
\text { than 1,005 USD) }\end{array}$} & $\begin{array}{c}\text { lower than the } \\
\text { average GNI per } \\
\text { capita (from 1,006 to } \\
\text { 3,955 USD) }\end{array}$ & $\begin{array}{c}\text { above average GNI per } \\
\text { capita (from 3956 to 12235 } \\
\text { USD) }\end{array}$ & $\begin{array}{c}\text { high GNI per capita (from } \\
\text { 12,236 USD or more) }\end{array}$ \\
\hline Benin & Armenia & Albania & Australia \\
\hline Burundi & Bangladesh & Algeria & Austria \\
\hline Chad & Bolivia & Argentina & Bahrain \\
\hline Ethiopia & Ghana & Botswana & Barbados \\
\hline Gambia & Guatemala & Brazil & Brunei \\
\hline Guinea & Honduras & Bulgaria & Canada \\
\hline Liberia & Egypt & China & Chile \\
\hline Madagascar & El Salvador & Colombia & Cyprus \\
\hline Malawi & Cambodia & Costa Rica & Denmark \\
\hline Mozambique & Cote d'Ivoire & Dominican Republic & \\
\hline
\end{tabular}

Source: built by the author according to Jahan et al., 2018. 
Table 2b. Ranking countries by GNI per capita (part 2)

\begin{tabular}{|c|c|c|c|}
\hline \multicolumn{4}{|c|}{ Countries } \\
\hline \multirow[b]{2}{*}{$\begin{array}{l}\text { low GNI per capita (less } \\
\text { than } 1,005 \text { USD) }\end{array}$} & \multicolumn{2}{|c|}{ average GNI } & \multirow[b]{2}{*}{$\begin{array}{l}\text { high GNI per capita (from } \\
12,236 \text { USD or more) }\end{array}$} \\
\hline & $\begin{array}{c}\text { lower than the } \\
\text { average GNI per } \\
\text { capita (from 1,006 to } \\
3,955 \text { USD) }\end{array}$ & $\begin{array}{c}\text { above average GNI per } \\
\text { capita (from } 3956 \text { to } 12235 \\
\text { USD) }\end{array}$ & \\
\hline Nepal & India & Ecuador & Estonia \\
\hline Rwanda & Indonesia & Gabon & Finland \\
\hline Senegal & Jordan & Guyana & France \\
\hline Sierra Leone & Kenya & Iran & Germany \\
\hline Tanzania & Kyrgyzstan & Jamaica & Greece \\
\hline Mali & Lesotho & Macedonia & Iceland \\
\hline \multirow[t]{20}{*}{ Uganda } & Mauritania & Malaysia & Ireland \\
\hline & Moldova & Mauritius & Israel \\
\hline & Mongolia & Mexico & Italy \\
\hline & Morocco & Namibia & Japan \\
\hline & Myanmar & Panama & Korea \\
\hline & Nicaragua & Paraguay & Kuwait \\
\hline & Nigeria & Peru & Latvia \\
\hline & Pakistan & Romania & Lithuania \\
\hline & Philippines & Russia & Luxembourg \\
\hline & Sri Lanka & Serbia & Malta \\
\hline & Swaziland & South Africa & Netherlands \\
\hline & Tajikistan & Thailand & New Zealand \\
\hline & Tunisia & Turkey & Norway \\
\hline & Ukraine & Venezuela & Poland \\
\hline & Vietnam & Croatia & Spain \\
\hline & Yemen & Kazakhstan & Sweden \\
\hline & Zambia & & Switzerland \\
\hline & Cameroon & & UAE \\
\hline & Laos & & Great Britain \\
\hline & & & USA \\
\hline
\end{tabular}

Source: built by the author according to Jahan et al., 2018. 
From each group, 10 indicative countries are selected to construct the matrix. The group of countries with high gross national income per capita (from 12,236 USD or more) includes Australia, Austria, Belgium, the United Kingdom, the United States, Germany, Japan, and Israel. The group of countries with higher than average gross national income per capita (from 3956 to 12235 USD) includes Bulgaria, China, the Dominican Republic, Romania, Turkey, Kazakhstan, Peru, and Mexico. Ukraine occupies slightly lower positions, entering the group of countries with lower than average gross national income per capita (from 1,006 to 3,955 USD). This group also includes Moldova, Kyrgyzstan, and India (Jahan et al., 2018).

The data for constructing correlation dependencies are given in the following tables. Human capital index indicators for countries with a high level of GNI per capita are shown in Table 3.

Table 3. Human capital index for countries with high GNI per capita

\begin{tabular}{ccc}
\hline Country & $\mathrm{HCl}$ & Country rank in HCl rating \\
\hline Australia & 0,79 & 7 \\
\hline Great Britain & 0,78 & 30 \\
\hline Poland & 0,75 & 18 \\
\hline Norway & 0,77 & 8 \\
\hline Sweden & 0,80 & 24 \\
\hline USA & 0,76 & 5 \\
\hline Finland & 0,81 & 3 \\
\hline Japan & 0,84 & 29 \\
\hline Estonia & 0,75 & 37 \\
\hline Lithuania & 0,71 & 30 \\
\hline
\end{tabular}

Source: The Human, 2018.

A high human capital development index is observed in developed countries such as Japan (3rd place), Finland (5th place in the rating), Australia (7th city in the rating). Comparison with the data on the human development index in accordance with the UNDP report gives the following result are shown in Fig. 2.

Not in all cases, the human capital index corresponds to the human development index, which is explained by a different methodology for determining indicators, which was also developed by completely different world institutions - the organization of unification of nations within the framework of UNDP and the World Bank in the document "Human Capital Development Project". In some cases, the data are significantly different. So, while Norway ranks first in terms of the human development index, in the ranking of the human capital index it is only 18. Former Soviet Union countries, Estonia and Lithuania rank 30 and 35 in the HDI, respectively, and 29 and 37 in the $\mathrm{HCl}$. 
Human Development Index for countries with high GNI per capita

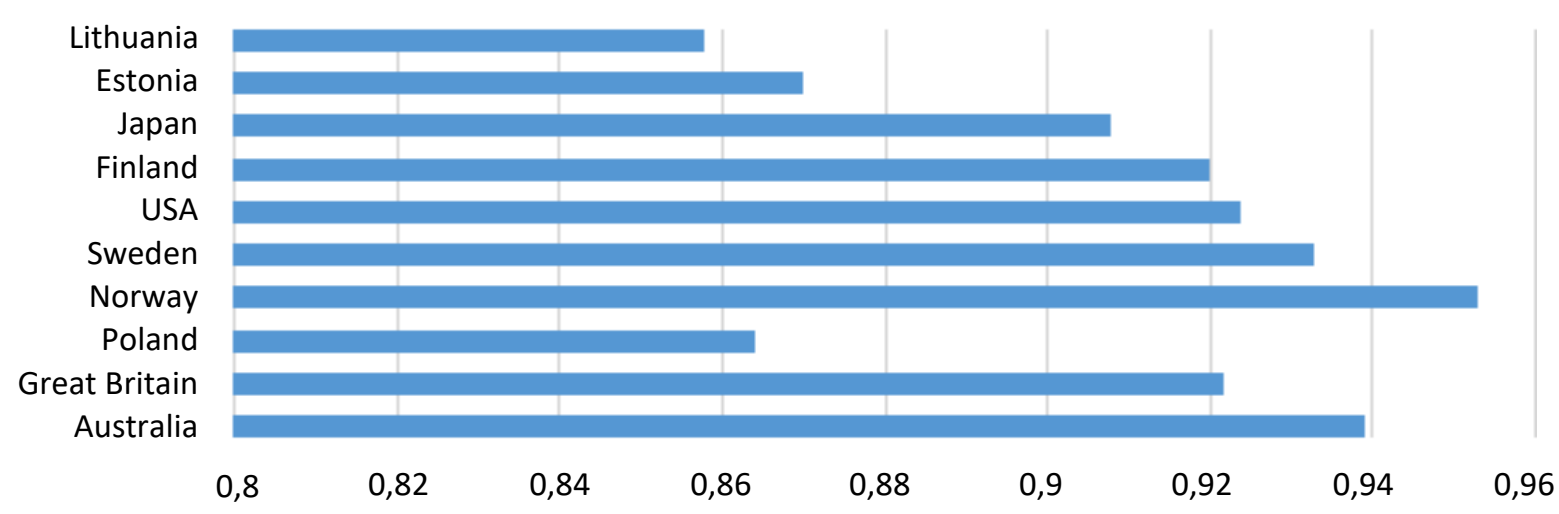

Figure 2. Human Development Index for countries with high GNI per capita, 2017 Source: built by the author according to Jahan et al., 2018.

Table $4 a$ and Table $4 b$ shows the data characterizing the development of the institutional system for constructing a matrix for countries with a high level of GNI per capita (Index, 2018).

Table 4a. Data for calculating the development indicators of the institutional system of countries with a high level of GNI per capita (part 1)

\begin{tabular}{|c|c|c|c|c|c|c|}
\hline Country & $\begin{array}{l}\text { business } \\
\text { freedom }\end{array}$ & $\begin{array}{c}\text { labor } \\
\text { market } \\
\text { freedom }\end{array}$ & $\begin{array}{l}\text { monetary } \\
\text { freedom }\end{array}$ & $\begin{array}{c}\text { trade } \\
\text { freedom }\end{array}$ & $\begin{array}{l}\text { investment } \\
\text { freedom }\end{array}$ & $\begin{array}{l}\text { financial } \\
\text { freedom }\end{array}$ \\
\hline Variable & $\mathrm{X} 1$ & $X 2$ & X3 & $X 4$ & $\times 5$ & X6 \\
\hline Australia & 89,1 & 79,7 & 87,4 & 86,2 & 80 & 90 \\
\hline Great Britain & 91,1 & 74,4 & 85,2 & 86,9 & 90 & 80 \\
\hline Poland & 67,2 & 63,9 & 85 & 86,9 & 75 & 70 \\
\hline Norway & 90,4 & 54,6 & 73,9 & 87,9 & 75 & 60 \\
\hline Sweden & 89,3 & 53,7 & 83,8 & 86,9 & 85 & 80 \\
\hline USA & 82,7 & 91,4 & 78,6 & 86,7 & 85 & 80 \\
\hline Finland & 89,9 & 50,5 & 86 & 86,9 & 85 & 80 \\
\hline Japan & 81,7 & 79,2 & 85,4 & 82,3 & 70 & 60 \\
\hline Estonia & 75,6 & 54,8 & 85,1 & 86,9 & 90 & 80 \\
\hline Lithuania & 73,4 & 64,5 & 89,9 & 86,9 & 80 & 70 \\
\hline
\end{tabular}

Source: Index, 2018. 
Table 4b. Data for calculating the development indicators of the institutional system of countries with a high level of GNI per capita (part 2)

\begin{tabular}{ccccccc}
\hline Country & $\begin{array}{c}\text { fiscal } \\
\text { health }\end{array}$ & $\begin{array}{c}\text { government } \\
\text { spending }\end{array}$ & tax burden & $\begin{array}{c}\text { government } \\
\text { decency }\end{array}$ & $\begin{array}{c}\text { judicial } \\
\text { efficiency }\end{array}$ & $\begin{array}{c}\text { protection } \\
\text { of } \\
\text { property } \\
\text { right }\end{array}$ \\
\hline Country & X7 & X8 & X9 & X10 & X11 & X12 \\
\hline Variable & 84,3 & 61,2 & 63 & 77,4 & 93,4 & 78,7 \\
\hline Great Britain & 53,5 & 44,4 & 65,2 & 79 & 93,8 & 92,2 \\
\hline Poland & 81,5 & 47,8 & 75,9 & 50,9 & 56,6 & 61,8 \\
\hline Norway & 97,8 & 29,2 & 56,4 & 93,6 & 86 & 86,4 \\
\hline Sweden & 96,1 & 23,2 & 43,9 & 92,9 & 88,2 & 92,6 \\
\hline USA & 54,8 & 56,5 & 65,1 & 71,9 & 76,9 & 79,3 \\
\hline Finland & 81,1 & 2,3 & 66,5 & 89,8 & 82,7 & 89 \\
\hline Japan & 49,3 & 54,1 & 67,4 & 79,2 & 73,2 & 86 \\
\hline Estonia & 99,8 & 52,6 & 80,7 & 75,7 & 83,9 & 80,4 \\
\hline Lithuania & 96,7 & 63,9 & 86,4 & 50,9 & 66,7 & 73,8 \\
\hline
\end{tabular}

Source: Index, 2018.

Table 5 provides indicators of the human capital index for countries with an average level of GNI per capita (The Human, 2018).

Table 5. Human capital index for countries with average GNI per capita

\begin{tabular}{ccc}
\hline Country & $\mathrm{HCl}$ & Country rank in HCl rating \\
\hline Kyrgyzstan & 0,58 & 76 \\
\hline Turkey & 0,63 & 53 \\
\hline Armenia & 0,57 & 78 \\
\hline Mexico & 0,61 & 64 \\
\hline Tajikistan & 0,53 & 89 \\
\hline China & 0,67 & 46 \\
\hline Ukraine & 0,65 & 50 \\
\hline Romania & 0,6 & 67 \\
\hline Bulgaria & 0,68 & 44 \\
\hline Moldova & 0,58 & 75 \\
\hline
\end{tabular}

Source: The Human, 2018. 
This group includes Ukraine, which ranked 50th in this World Bank rating. At the same time, China is observed along with Ukraine - 46th place. Turkey is on the 53rd place. The countries of the former Soviet space - Moldova, Kyrgyzstan, Armenia, Tajikistan - occupy 75, 76, 78, 89 places respectively.

Human development data for countries with average per capita GNI are shown in Fig. 3.

Human Development Index for countries with average GNI per capita

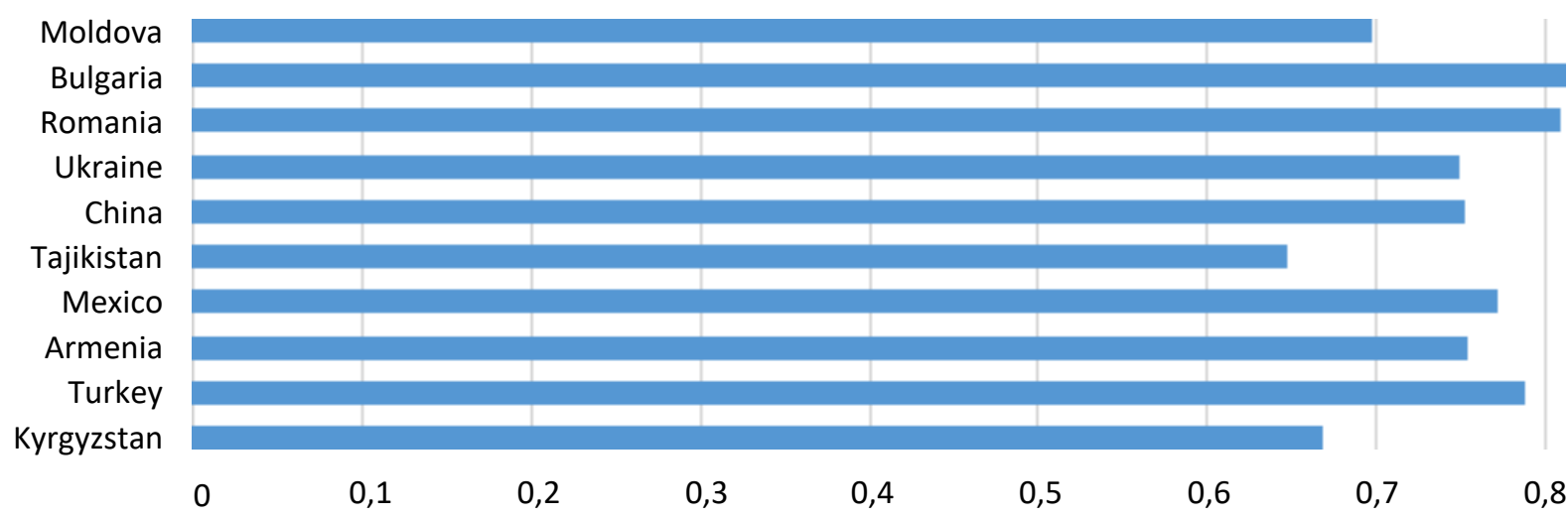

Figure 3. Human development index for countries with average GNI per capita, 2017

Source: built by the author according to Jahan et al., 2018.

A comparison of the human capital index with the data on the human development index in accordance with the UNDP report gives the following result. In some cases, the data are significantly different. According to UNDP, Ukraine takes 88th place in terms of human development, which is taken into account as an average indicator of the level of human development. In the group of countries with an average level of GNI per capita among the above former countries of the Soviet Union, Armenia occupies the highest city 83 (5 positions higher than Ukraine).

Table 6 shows the data characterizing the development of the institutional system for constructing a matrix for countries with an average GNI per capita (Index, 2018). 
Table 6. Data for calculating the development indicators of the institutional system of countries with an average level of GNI per capita

\begin{tabular}{|c|c|c|c|c|c|c|}
\hline Country & $\begin{array}{l}\text { business } \\
\text { freedom }\end{array}$ & $\begin{array}{c}\text { labor market } \\
\text { freedom }\end{array}$ & $\begin{array}{l}\text { monetary } \\
\text { freedom }\end{array}$ & $\begin{array}{c}\text { trade } \\
\text { freedom }\end{array}$ & $\begin{array}{c}\text { investment } \\
\text { freedom }\end{array}$ & $\begin{array}{l}\text { financial } \\
\text { freedom }\end{array}$ \\
\hline Variable & $\mathrm{X} 1$ & $\mathrm{X} 2$ & X3 & $\mathrm{X} 4$ & $\times 5$ & $x 6$ \\
\hline Kyrgyzstan & 73,3 & 77,9 & 74,9 & 74,5 & 60 & 50 \\
\hline Turkey & 63,3 & 47,6 & 72,3 & 78,6 & 75 & 60 \\
\hline Armenia & 78,7 & 69,9 & 75,8 & 80 & 75 & 70 \\
\hline Mexico & 67,5 & 59,8 & 79,2 & 88 & 75 & 60 \\
\hline Tajikistan & 63,4 & 52,2 & 69,6 & 70,6 & 25 & 30 \\
\hline China & 54,9 & 61,4 & 71,4 & 73,2 & 25 & 20 \\
\hline Ukraine & 62,7 & 52,8 & 60,1 & 81,1 & 35 & 30 \\
\hline Romania & 65,2 & 66,8 & 82,8 & 86,9 & 75 & 50 \\
\hline Bulgaria & 64,3 & 66,1 & 82,8 & 86,9 & 70 & 60 \\
\hline Moldova & 66 & 39,9 & 73,2 & 78,3 & 55 & 50 \\
\hline Country & fiscal health & $\begin{array}{l}\text { government } \\
\text { spending }\end{array}$ & tax burden & $\begin{array}{c}\text { government } \\
\text { decency }\end{array}$ & $\begin{array}{l}\text { judicial } \\
\text { efficiency }\end{array}$ & $\begin{array}{c}\text { protection } \\
\text { of property } \\
\text { right }\end{array}$ \\
\hline Variable & $x 7$ & $\mathrm{X} 8$ & $\mathrm{X9}$ & $\mathrm{X} 10$ & $\mathrm{X} 11$ & $\mathrm{X} 12$ \\
\hline Kyrgyzstan & 89,2 & 58,2 & 93,8 & 29,4 & 22,1 & 50,2 \\
\hline Turkey & 93,6 & 68,1 & 74,7 & 42 & 54,5 & 54,7 \\
\hline Armenia & 67,2 & 80 & 84,7 & 40,5 & 47,4 & 55,3 \\
\hline Mexico & 69,8 & 78,1 & 75,7 & 26,9 & 39 & 58,6 \\
\hline Tajikistan & 90,4 & 71,4 & 91,8 & 38,2 & 50,3 & 46,8 \\
\hline China & 85,9 & 71,6 & 70,4 & 47,3 & 65,4 & 46,7 \\
\hline Ukraine & 75,9 & 45 & 80,2 & 29 & 29,5 & 41 \\
\hline Romania & 91,1 & 66,9 & 87,3 & 40 & 59,7 & 61 \\
\hline Bulgaria & 94,3 & 60,5 & 90,9 & 38,2 & 42,5 & 63,6 \\
\hline Moldova & 90 & 56,7 & 85,3 & 26,6 & 26,3 & 53,5 \\
\hline
\end{tabular}

Source: Index, 2018.

Table 7 provides indicators of the human capital index for countries with a low level of GNI per capita (The Human, 2018). 
Table 7. Human capital index for low per capita GNI countries

\begin{tabular}{ccc}
\hline Country & $\mathrm{HCl}$ & Country rank in HCl rating \\
\hline Guinea & 0,37 & 141 \\
\hline Senegal & 0,42 & 121 \\
\hline Madagascar & 0,37 & 140 \\
\hline Nepal & 0,49 & 102 \\
\hline Benin & 0,41 & 127 \\
\hline Gambia & 0,4 & 130 \\
\hline Ethiopia & 0,38 & 135 \\
\hline Tanzania & 0,4 & 128 \\
\hline Chad & 0,29 & 157 \\
\hline Mozambique & 0,36 & 148 \\
\hline
\end{tabular}

Source: The Human, 2018.

This group includes the poorest countries of the modern world - Mozambique, Guinea, Madagascar, Chad, Ethiopia. In the ranking of the human development index, they rank from 152 to 189. Human development data for these countries are shown in Fig. 4.

Human Development Index for low GNI countries per capita

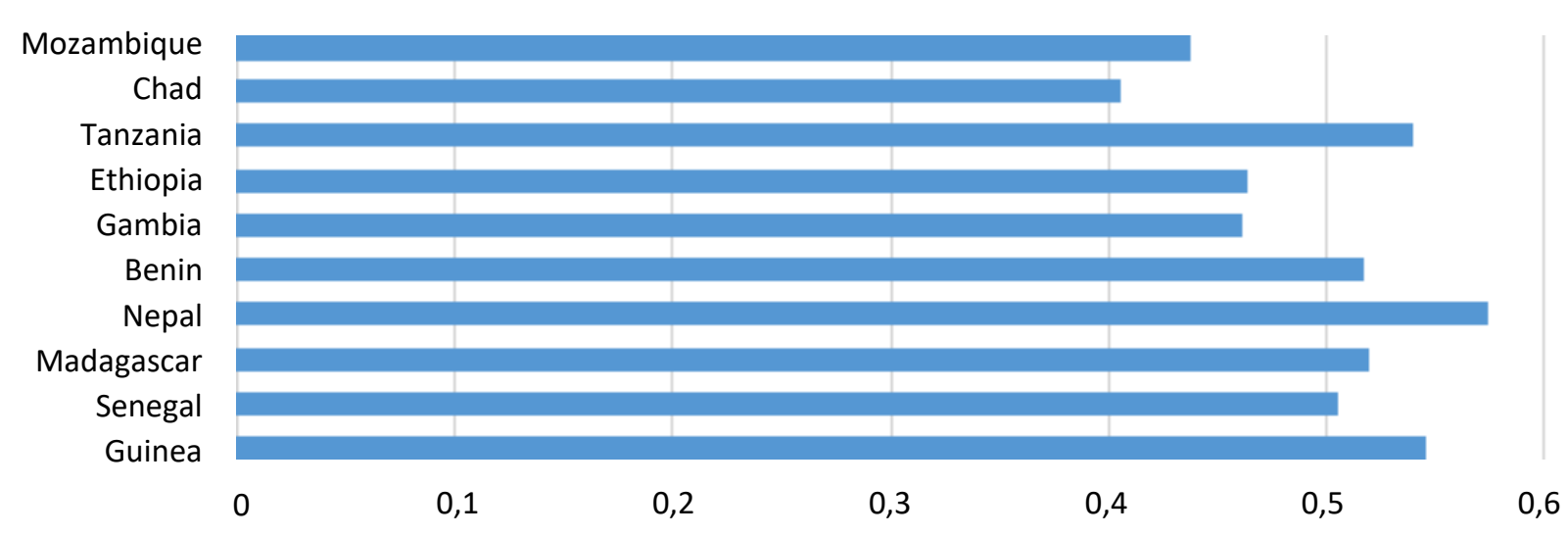

Figure 4. Human Development Index for low GNI countries per capita, 2017

Source: built by the author according to Jahan et al., 2018.

Data characterizing the development of the institutional system for constructing a matrix for countries with a low level of GNI per capita is shown in Table 8 (Index, 2018). 
Table 8. Data for calculating the development indicators of the institutional system of countries with a low level of GNI per capita

\begin{tabular}{|c|c|c|c|c|c|c|}
\hline Country & $\begin{array}{l}\text { business } \\
\text { freedom }\end{array}$ & $\begin{array}{c}\text { labor market } \\
\text { freedom }\end{array}$ & $\begin{array}{l}\text { monetary } \\
\text { freedom }\end{array}$ & $\begin{array}{c}\text { trade } \\
\text { freedom }\end{array}$ & $\begin{array}{c}\text { investment } \\
\text { freedom }\end{array}$ & $\begin{array}{l}\text { financial } \\
\text { freedom }\end{array}$ \\
\hline Variable & $\mathrm{X} 1$ & $\mathrm{X} 2$ & X3 & $X 4$ & $\times 5$ & $\mathrm{x} 6$ \\
\hline Guinea & 54,1 & 54 & 71,8 & 61,2 & 50 & 40 \\
\hline Senegal & 51,5 & 41,4 & 84,7 & 66,7 & 60 & 40 \\
\hline Madagascar & 45,6 & 41,5 & 73,4 & 78 & 55 & 50 \\
\hline Nepal & 64,6 & 43,5 & 65,8 & 66,6 & 10 & 30 \\
\hline Benin & 60,7 & 49,9 & 84,7 & 55,6 & 80 & 50 \\
\hline Gambia & 54,2 & 64 & 63,2 & 64,7 & 75 & 50 \\
\hline Ethiopia & 40,2 & 51,3 & 67,1 & 60,7 & 35 & 20 \\
\hline Tanzania & 50 & 63,9 & 70,3 & 76,9 & 55 & 50 \\
\hline Chad & 29,4 & 40,3 & 79,9 & 52,2 & 60 & 40 \\
\hline Mozambique & 58 & 37,8 & 66,7 & 76,7 & 35 & 50 \\
\hline Country & fiscal health & $\begin{array}{l}\text { government } \\
\text { spending }\end{array}$ & tax burden & $\begin{array}{c}\text { government } \\
\text { decency }\end{array}$ & $\begin{array}{l}\text { judicial } \\
\text { efficiency }\end{array}$ & $\begin{array}{c}\text { protection } \\
\text { of property } \\
\text { right }\end{array}$ \\
\hline Variable & $\mathrm{X7}$ & $\mathrm{x} 8$ & $\times 9$ & $\mathrm{X} 10$ & $\mathrm{X} 11$ & $\mathrm{X} 12$ \\
\hline Guinea & 61 & 80,6 & 65,9 & 26,9 & 28,2 & 32,4 \\
\hline Senegal & 58,4 & 72,7 & 68,5 & 42,6 & 40,4 & 41,3 \\
\hline Madagascar & 82,5 & 92,9 & 90,3 & 17,8 & 21,4 & 33,2 \\
\hline Nepal & 98,5 & 87,6 & 84,2 & 24,6 & 36,2 & 37,5 \\
\hline Benin & 49,7 & 85,6 & 67,4 & 30,2 & 31,3 & 35,5 \\
\hline Gambia & 0 & 74 & 71,9 & 36,8 & 38,8 & 34,4 \\
\hline Ethiopia & 85,5 & 90,6 & 76,5 & 37,7 & 37,6 & 31,1 \\
\hline Tanzania & 79 & 89,8 & 79,8 & 31,8 & 34,7 & 38 \\
\hline Chad & 81,9 & 90,5 & 44,8 & 23,1 & 24,1 & 25,1 \\
\hline Mozambique & 0 & 60,7 & 70,6 & 28,2 & 36,3 & 35,4 \\
\hline
\end{tabular}

Source: Index, 2018.

To study the qualitative and quantitative assessment of the relationships between the level of development of the country's human capital and institutional factors of influence, multivariate correlation and regression analysis is used. To calculate, it is suggested to use the formula: 


$$
Y=f(\beta, X)+\varepsilon,
$$

where $Y$-dependent variable;

$X=X\left(X_{1}, X_{2}, \ldots, X_{m}\right)$ - independent variables (political and legal factors, economic factors, social factors, organizational and administrative and information and communication factors, scientific and technological factors, institutional factors);

$\beta=\beta\left(\beta_{0}, \beta_{1}, \beta_{2}, \ldots, \beta_{m}\right)$ - regression coefficient;

$\varepsilon-$ random error.

In order to determine the dependence of human capital development on the level of development of the country's institutional system in the information economy, let's construct twelve-factor correlation and regression models for 157 countries, which are combined into three groups according to the level of gross national income per capita. To calculate, it is suggested to use the formula:

1) for countries with a high level of gross national income per capita:

$$
\begin{gathered}
Y_{1}=0,36+0,05 X 1+0,05 X 2+0,04 X 3+0,06 X 4+0,02 X 5+0,05 X 6+0,06 X 7+ \\
+0,08 X 8+0,10 X 9+0,04 X 10+0,04 X 11+0,05 X 12
\end{gathered}
$$

2) for countries with an average level of gross national income per capita:

$$
\begin{aligned}
Y_{2}= & 0,28+0,04 X 1+0,12 X 2+0,04 X 3+0,03 X 4+0,02 X 5+0,03 X 6+ \\
& +0,04 X 7+0,07 X 8+0,08 X 9+0,05 X 10+0,06 X 11+0,10 X 12
\end{aligned}
$$

3) for countries with a low level of gross national income per capita:

$$
\begin{aligned}
Y_{3}= & 0,19+0,02 X 1+0,03 X 2+0,01 X 3+0,05 X 4+0,01 X 5+0,02 X 6+ \\
& +0,01 X 7+0,05 X 8+0,04 X 9+0,07 X 10+0,08 X 11+0,06 X 12
\end{aligned}
$$

Calculation of the correlation matrix provided an opportunity to conclude that there is a significant relationship between the effective indicator and factor values. The multiple determination coefficient $r^{2}$ is 0.53 , therefore, the effective indicator depends on 12 factors by $53 \%$. The multiple correlation coefficient of 0.728 indicates a close relationship between the indicators and is significant and random (according to the F-criterion).

\section{Conclusions}

It is revealed the relationship between the human capital index and the development of the country's institutional system. The selection of indicators describing the dependence of the development of human capital on the development of the country's institutional system in the information economy, which included political, legal, economic, social, institutional, using an expert analysis method, is carried out. 
For a multifactorial phenomenon, as the dependence of the development of human capital on the level of development of the country's institutional system in the information economy, the methods of multiple correlation and regression analysis are used. The study is conducted for 157 countries of the world for which the World Bank determined the country's human capital index in 2018. As a result, correlation equations are constructed that describe the dependence of the development of human capital on the level of development of the country's institutional system in the information economy. They should determine the feasibility of material costs for the development of a separate factor of the influence of the institutional system for the development of human capital.

The constructed models show that the greatest correlation between the human capital index and the selected indicators of the country's institutional system development exists: for countries with a high human capital index and high gross national income per capita government labor costs, tax burden; for countries with an average human capital index and with an average gross national income per capita, to which Ukraine belongs, freedom of the labor market, protection of property rights; for countries with a low human capital index and low gross national income per capita - the effectiveness of the judicial system, government decency.

According to the calculated regression coefficients, it is established to what extent human capital is sensitive to the variability of the institutional system, it makes it possible to assess how much and what factors delay and accelerate the development of human capital, and the ability to develop forecasts of changes in the level of human capital.

\section{References}

Ali, M., Egbetokun, A., \& Memon, M. (2018). Human capital, social capabilities and economic growth. Economies, 6(2), 1-18. https://doi.org/10.3390/economies6010002

Becker, G. S. (1964). Human Capital: A Theoretical and Empirical Analysis, with Special Reference to Education. Chicago: University of Chicago Press. https://doi.org/10.1177/000271626536000153

Bryukhovetska, N. Yu., \& Chorna, O. A. (2015). Upravlinnia rozvytkom liudskoho kapitalu pidpryiemstv: instytutsionalnyi aspekt [Management of human capital the development of enterprises: institutional aspect]. Kyiv: Institute of Industrial Economics of the National Academy of Sciences of Ukraine. Retrieved from https://iie.org.ua/monografiyi/bryuhovetska-n-yu-chorna-o-a-upravlinnyarozvitkom-lyudskogo-kapitalu-pidpriyemstv-institutsionalniy-aspekt-2015-r/

Dalevska, N., Khobta, V., Kwilinski, A., \& Kravchenko, S. (2019). A model for estimating social and economic indicators of sustainable development. Entrepreneurship and Sustainability Issues, 6(4), 1839-1860. https://doi.org/10.9770/jesi.2019.6.4(21)

Flamholtz, E. G, Bullen, M. L., \& Hua, W. (2002). Human resource accounting: a historical perspective and future implications. Management Decision, 40(10), 947-954. Retrieved from https://www.academia.edu/3355572/Human_resource_accounting_a_historical_perspective _and_future_implications 
Jahan, S., \& et al. (2018). Human Development Indices and Indicators: 2018 Statistical Update. New York, NY: The United Nations Development Programme. Retrieved from http://hdr.undp.org/sites/default/files/2018_human_development_statistical_update.pdf

Kolomiiets, V., \& Golovkova, L. (2017). The institutional content of the human capital of the national economy. Baltic Journal of Economic Studies, 3(5), 289-293. https://dx.doi.org/10.30525/22560742/2017-3-5-289-293

Kwilinski, A., Pajak, K., Halachenko, O., Vasylchak, S., Pushak, Ya., \& Kuzior, P. (2019). Marketing Tools for Improving Enterprise Performance in the Context of Social and Economic Security of the State: Innovative Approaches to Assessment. Marketing and Management of Innovations, 4, 172-181. http://doi.org/10.21272/mmi.2019.4-14

Liashenko, N. Ye. (2016). Elektronne portfolio yak zasib formalizatsii liudskoho kapitalu firmy [Electronic portfolio as a tool of formalization the company's human capital]. Upravlinnia proektamy ta rozvytok vyrobnytstva - Project Management and Production Development, 4(60), 18-29. Retrieved from http://www.pmdp.org.ua/images/Journal/60/2_Lyashenko\%20N.pdf [in Ukrainian].

Liashenko, P. A. (2017). Diapazon rozuminnia ekonomichnoho rozvytku rehionu [Range of understanding of the region's economic development]. Upravlinnia proektamy ta rozvytok vyrobnytstva - Project Management and Production Development, 2(62), 122-126. Retrieved from http://www.pmdp.org.ua/images/Journal/62/9.pdf [in Ukrainian].

Lyashenko, V., \& Pidorycheva, I. (2019). The formation of interstate and cross-border scientificeducational and innovative spaces between Ukraine and the European Union member states in the digital economy. Virtual Economics, 2(2), 48-58. https://doi.org/10.34021/ve.2019.02.02(3)

Mahmood, H., \& Alkahtani, N. (2018). Human resource, financial market development and economic growth in Saudi Arabia: a role of human capital. Economic Annals-XXI, 169(1-2), 31-34. https://doi.org/10.21003/ea.V169-06

Miller, T., Kim, A. B., \& Roberts, J. M. (2018). Index of Economic Freedom. Washington, D.C.: The Heritage Foundation. Retrieved from https://www.heritage.org/index/pdf/2018/book/index_ 2018.pdf

Pająk, K., Kamińska, B., \& Kvilinskyi, O. (2016). Modern trends of financial sector development under the virtual regionalization conditions. Financial and Credit Activity: Problems of Theory and Practice, 2(21), 204-217. https://doi.org/10.18371/fcaptp.v2i21.91052

Proekt razvitiya chelovecheskogo kapitala [Human Capital Development Project] (2018). Washington, D.C.: World Bank. Retrieved from https://openknowledge.worldbank.org/bitstream/handle/ 10986/30498/33324RU.pdf? sequence=13\&isAllowed=y [in Russian].

Radieva, M. (2018). Institutional modernization of the Global economy. Baltic Journal of Economic Studies, 4(5), 283-290. https://doi.org/10.30525/2256-0742/2018-4-5-283-290

Radieva, M., Tkach, A., Kolomiiets, V., Rekun, I., Tkach, T., \& Zolkina, O. (2018). Transformatsiini protsesy $v$ ekonomitsi: instytutsionalnyi kontekst [Transformation Processes in Economics: An Institutional Context]. Melitopol: Color Print. https://doi.org/10.32901/978-966-2489-64-4/2018 [in Ukrainian].

Roslender, R. (2009). The prospects for satisfactorily measuring and reporting intangibles: Time to embrace a new model of (ac)counting? Journal of Human Resource Costing \& Accounting, 13(4), 338-359. https://doi.org/10.1108/14013381011010169 
Shashyna, M. V. (2018). Tendentsii zmin instytutsiionalnoho seredovyshcha Ukrainy [Trends in changes in the institutional environment of Ukraine]. Ekonomika, finansi, pravo - Economics, finance, law, 12(5), 26-31. Retrieved from http://konferencia.com.ua/images/_archieve/ 2018/efp\%20125\%202018.pdf [in Ukrainian].

Siddiqui, A., \& Rehman, A. ur (2016). The Human Capital and Economic Growth Nexus: in East and $\begin{array}{llll}\text { South Asia. } & \text { Applied }\end{array}$ https://doi.org/10.1080/00036846.2016.1245841 